\title{
MODELLING OF SLOPE PROCESSES ON KARST
}

\section{MODELIRANJE POBOČNIH PROCESOV NA KRASU}

\author{
Uroš STEPIŠNIK ${ }^{1} \&$ Gregor KOSEC $^{2}$
}

\begin{abstract}
UDC 911.2:551.435(497.471)

Uroš Stepišnik \& Gregor Kosec: Modelling of slope processes on karst

The present paper is concerned with the modelling of the karst slope processes. A simple straightforward one dimensional physical model is introduced in order to assess basic behaviour of the slope development. The model takes in account mass continuity of weathered material, the mechanical and chemical weathering of the bedrock. The paper focuses on the slope formation with respect to the ratios between different magnitudes of governing processes (mechanical and chemical weathering and mass movement). The introduced approach representsa first step in understanding slope processes and does not pose a realistic quantitative comparison with field measurements. However, the results gathered with the model show good qualitative agreement with the field observations. Three different representative cases are studied: dominant mechanical weathering case, balanced mechanical and chemical weathering case and dominant chemical weathering case.

Key words: Karst, slopes, weathering, mass movement, modelling, diffusion, convection.
\end{abstract}

Izvleček

UDK 911.2:551.435(497.471)

Uroš Stepišnik \& Gregor Kosec: Modeliranje pobočnih procesov na krasu

Članek obravnava modeliranje pobočnih procesov na krasu. Predstavljen je preprost enodimenzionalen fizikalni model preko katerega se oceni temeljno obnašanje pobočnih procesov. Model upošteva masno kontinuiteto prepereline ter mehanično in kemično preperevanje matične kamnine. Članek podrobneje obravnava oblikovanje pobočij pri različnih intenzivnostih prevladujočih procesov (mehansko in kemično preperevanje ter pobočni procesi). Uporabljen pristop predstavlja prvi korak $\mathrm{k}$ razumevanju pobočnih procesov, vendar ne vsebuje primerjav z realnimi terenskimi meritvami. Podatki pridobljeni s predstavljenim modelom kažejo dobro kvalitativno ujemanje s terenskimi opazovanji. Podrobneje so predstavljeni trije tipični primeri: primer prevladujočega mehanskega preperevanja, primer uravnoteženega mehanskega in kemičnega preperevanja ter primer prevladujočega kemičnega preperevanja.

Ključne besede: Kras, pobočja, preperevanje, pobočni proces, modeliranje, difuzija, konvekcija.

\section{INTRODUCTION}

Most of the geomorphological research of the second half of the twentieth century was devoted to slope development over time (Chorley \& Kennedy 1971; Carson \& Kirkby 1972; Kirkby 1978; Summerfield 1991). Several geomorphological models describing slope formation were proposed; with the models of Davis, Penck and King (Summerfield 1991) most widely discussed.
Davis has developed a model of slope lowering which leads to a reduction of slope inclination over time. The upper part of the slope becomes convex and lower part becomes concave. The final result of slope development is a peneplain. Penck's slope replacement model describes a reduction of steep rocky slopes which in lower parts are replaced with more gentle, regularly concave

\footnotetext{
${ }^{1}$ University of Ljubljana, Department of Geography, Aškerčeva 2, SI-1000 Ljubljana, Slovenia, e-mail: uros.stepisnik@gmail.com

${ }^{2}$ Jožef Stefan Institute, Jamova cesta 39, SI-1000 Ljubljana, Slovenia, e-mail: grega.kosec@gmail.com
}

Received/Prejeto: 23.07.2011 
slope. This model does not define the final stage of slope development as it is applied to the areas of tectonic uplift in the Andes and the Alps. King's slope withdrawal model explains the parallel retreat of slope without changing the angle of the upper part of the slope. Weathered material accumulates only in the lower parts of slopes which are concave. Under the slopes pediments are formed (Summerfield 1991). These classical models of slope development are not based on detailed studies of the slopes and do not provide detailed information about the development dynamics of certain slope types but stand for starting point for further study of slope development.

Subsequent literature (Carson\& Kirkby 1972; Kirkby 1978; Anhert 1987; Anderson \& Richards 1987) specifies the evolution of slope in time as a function of lithological and mechanical characteristics of rocks and types of processes on the slopes. Retreat of the slopes is parallel only if the mechanical properties of the bedrock are uniform and simultaneous removal of accumulation at footslope is active. Parallel slope retreat is common even if the upper part of slope is of mechanically more resistant bedrock than lower part (Summerfield 1991).

Geomorphic processes on karst slopes differ from those on slopes in other geomorphic systems. They are limited only to mechanical and chemical weathering of bedrock, mass movement and accumulation of weathered material at the footslope. No processes connected with surface water runoff or water accumulation in a weathered mantle are present on karst slopes. Better recognition of the nature and dynamics of geomorphic processes operating on karst slopes would enhance understanding of the development of the karst surface as

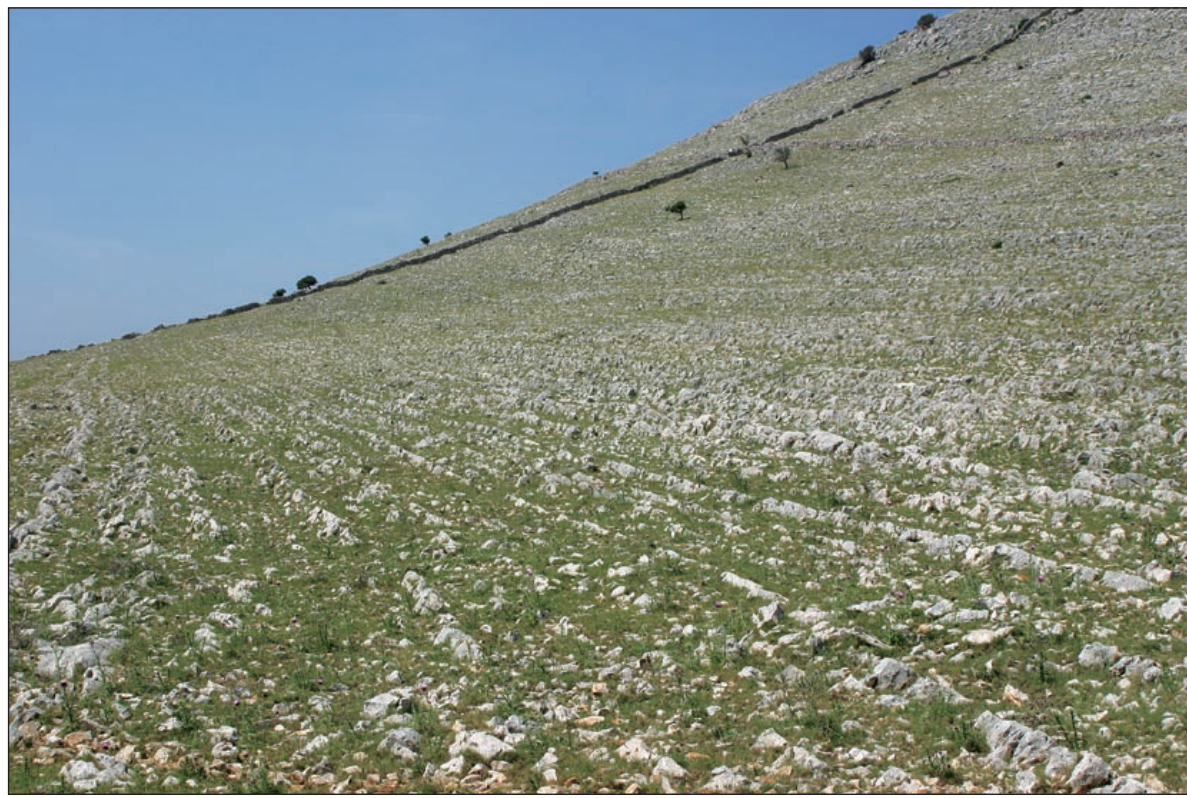

Fig. 1: Middle section of balanced slope on karst, Kornat, Croatia (Photo: K. Natek). a whole as well as the diversity of karst landforms with slopes.

Rock turns into transportable material by weathering. Slope formation in karst is dominated by two processes: mechanical and chemical weathering. Mechanical weathering causes disintegration of solid bedrock into smaller fractions generating weathered mantle which is then subjected to mass movement on the slope. The movement rate depends on slope angle and thickness of the mantle. At the same time, chemical weathering in the epikarstic zone causes dissolution of the weathered mantle. The material is then washed into the karstic aquifer as a solution. Both phenomena affect the thickness of the weathered mantle and the dynamics of its downslope movement.

A simple classification of karst slopes is based on dominant weathering type (Stepišnik 2006, 2008) with slopes being divided into active and balanced. On active slopes mechanical weathering of the bedrock is more rapid than chemical weathering of the weathered mantle. As a consequence, regolith is prone to mass movement parallel to slope (rockfalls, creep of weathered mantle etc.) Balanced slopes have equal or more intense chemical weathering than mechanical breakdown of bedrock. As a result most of the weathered mantle is dissolved in-situ and washed vertically into karst aquifer; it is not subjected to significant slope movement.

Those balanced slopes are unique for karst as their shape and inclination remain unchanged due to the absence of mass wasting on the slopes. Those slopes are modified mostly by dissolutional surface lowering, which functions normal to the slope and does not notably affect slope morphology. Once they reach a balanced state, the slopes on karst surface become stable and are normally bare or covered with only a very thin layer of regolith. Consequently, all slopes within surface features such as dolines will be preserved on that surface for an extremely long time.

The aim of this work is to upgrade the qualitative understanding of described processes with a physically based model. We follow simple and understandable assumptions in order to create another step towards better understanding of processes in karst systems. 


\section{PHYSICAL MODEL}

We propose a simple physical model to simulate the development of karst slopes. The present model is based

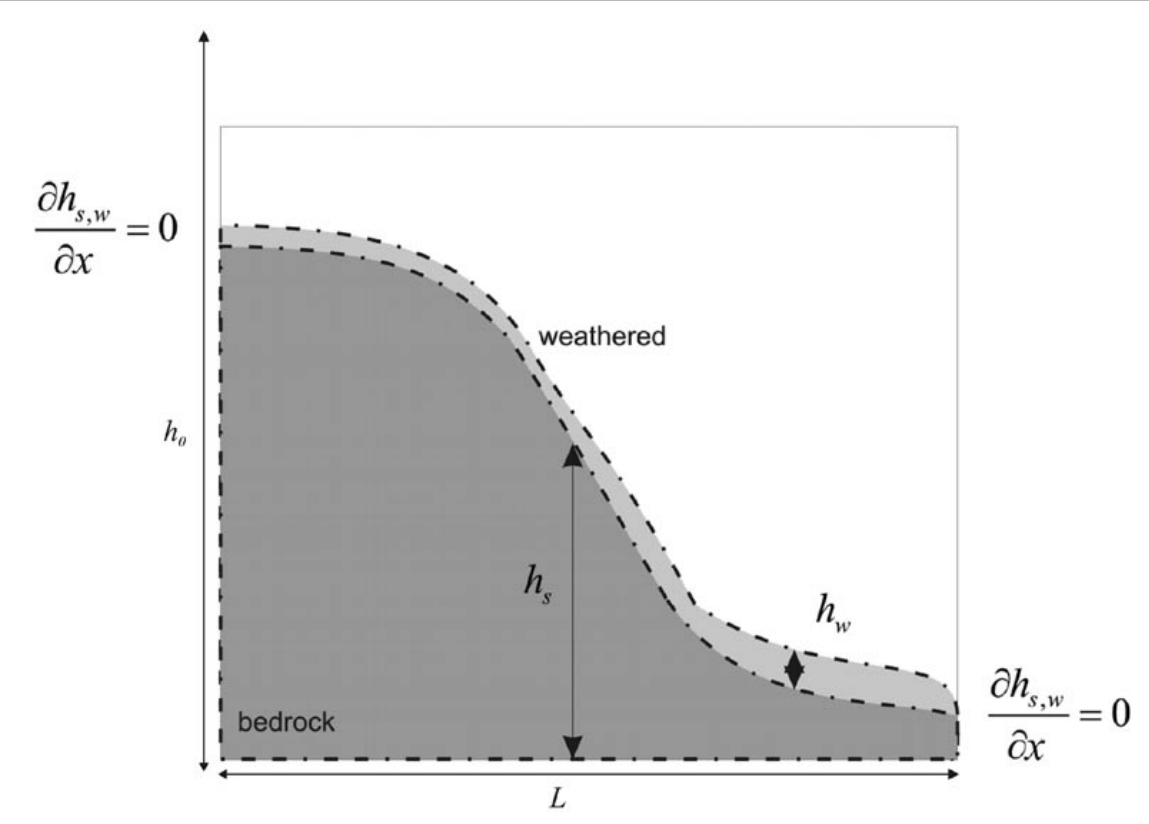

Fig. 2: Model setup.

on the work of G. Kaufmann work (Kaufmann 2002; Kaufmann 2009), where slope processes are modelled as a diffusive problem. Kaufmann incorporated all involving phenomena in a single process, the mass continuity, where he assumed that the mass flow depends only on the slope gradient. The result of such approach is diffusion equation, similar to the heat conduction whereas the temperature (or enthalpy) is replaced with height. In this work more a detailed treatment is presented. The bedrock and weathered material are treated as different materials with different physical behaviour. The bedrock is assumed not to be affected by disolutional lowering (note that focus of a present study is on the slope shape and not the absolute height) and to be steady (there is no material transport present). On the other hand, the regolith is transported downslope by gravity. To model the phenomena, simple advective-diffusive approach is proposed. The diffusive part of the transport plays similar role as in Kaufmann work, however the introduction of multi-material approach (bedrock-weathered mantle) demands additional transport mechanism in order to take in account the bedrock shape, i.e. to consider the bedrock gradient.

A next important phenomenon is the mechanical weathering of the bedrock. The bedrock is constantly transformed to the weathered material by the elements. In the present work those elements are assumed to be constant. However, the weathering rate is not constant as the weathered material insulates the bedrock and therefore the rate of weathering decreases with depth of the regolith.

Third, and the last process considered in the present work is dissolution of the weathered mantle. Similar to the mechanical weathering, the disolutional lowering of the surface depends only on the thickness of the weathered material. It is assumed to be more intense when more weathered material is present.

In this paper we deal only with one dimensional case (with Cartesian coordinate $x$ ). The setup of the test case is presented in Fig. 2.

As described, the weathered material transport is modelled as

$$
\begin{aligned}
\frac{\partial h_{w}}{\partial t}= & \underbrace{\frac{\partial}{\partial x} \cdot\left(\alpha_{w} \frac{\partial}{\partial x} h_{w}\right)}_{\text {difiision }}+\underbrace{\frac{\partial}{\partial x} \cdot\left(h_{w} v\right)}_{\text {advection }}-\underbrace{\gamma_{w} h_{w}}_{\text {corrosion }}+\underbrace{\frac{\rho_{s}}{\rho_{w}} \frac{\partial h_{s}}{\partial t}}_{\text {mechanioal weathering }}, \\
v & =\left\{\begin{array}{c}
0 ; \quad \frac{\partial h_{s}}{\partial x} \leq \xi_{\lim } \\
\beta_{w}\left(\frac{\partial h_{s}}{\partial x}\right)^{2} ; \frac{\partial h_{s}}{\partial x}>\xi_{\lim }
\end{array}\right.
\end{aligned}
$$

Where $h_{w}, \alpha_{w}, \beta_{w}, h_{s}, \gamma_{w}, \xi_{\text {lim }}, \rho_{w}$ and $\rho_{s}$ are weathered mantle thickness, weathered mantle diffusion coefficient, weathered mantle advection coefficient, bedrock height, corrosion coefficient, the limiting angle after which advection transport is not possible anymore, weathered material density and bedrock density, respectively. In Equation (1) all described processes are taken into account. First and second terms stand for transport mechanics, third term stand for corrosion and fourth for mechanical weathering, where density change is taken in account, as well. The "velocity" for the advection term is computed from the gradient of the bedrock (Eq. 2), 
where the limit gradient after which no transport is present, is taken in account. The construction of Eq. 2 is based on the field observations and is still open for further improvements.

In order to complete the model, additional relation describing the bedrock weathering is needed

$$
\frac{\partial h_{s}}{\partial t}=\frac{\varepsilon_{s}}{\rho_{s}\left(R_{w} h_{w}+1\right)},
$$

with $\varepsilon_{w}, R_{w}$ and $R_{0}$ the mechanical weathering coefficient, weathered isolation coefficient, and reference isolation coefficient, respectively. Eq. 3 is based on the model assumption that the rate of weathering depends only on the thickness of the weathered material and it is highest when no weathered material is present.

The construction of the present model is based on analogies from treatment of multiphase systems. The simplest multiphase solid-liquid system (ice-water) has been extensively studied by Josef Stefan around 1890 (Kamenomostskaya 1961; Meirmanov 1992; Šarler 1995).

This paper deals with the slope processes in general and it does not pose the quantitative results, therefore a convenient approach is to introduce dimensionless variables (denoted by tilde), equations and numbers in order to characterize behaviour of the physical model:

$$
\begin{gathered}
\tilde{x}=\frac{x}{L}, \\
\tilde{v}=\frac{L}{\alpha} v,
\end{gathered}
$$

$$
\begin{gathered}
\tilde{h}_{w}=\frac{h_{w}}{h_{0}}, \quad \tilde{h}_{s}=\frac{h_{s}}{h_{0}}, \\
\tilde{t}=\frac{\alpha}{L^{2}} t,
\end{gathered}
$$

where $L$ and $h_{o}$ stand for domain length and initial difference between highest and lowest height of bedrock.

The initial height of bedrock is set to a known function with a jump in the middle of the domain (kind

of a smoothed step function) and in the beginning of the simulation there is no weathered material present.

$$
\begin{gathered}
\tilde{h}_{s}(\tilde{t}=0)=h_{0} \frac{\tanh (-35(\tilde{x}-0.5))+1}{2}, \\
\tilde{h}_{w}(\tilde{t}=0)=0 .
\end{gathered}
$$

The physical model can be fully determined by following dimensionless numbers

$$
\begin{aligned}
& A_{1}=\frac{\gamma L^{2}}{\alpha}, \\
& A_{2}=\frac{\rho_{s}}{\rho_{w}} \frac{\varepsilon L^{2}}{h_{0} \alpha}, \\
& A_{3}=R_{w} h_{0}, \\
& A_{4}=\frac{h_{0}^{2}}{L} \frac{\beta}{\alpha} .
\end{aligned}
$$

First dimensionless number characterises corrosion, second and third weathering and the last one transport of the weathered material.

\section{RESULTS AND DISCUSSION}

The presented model does not have a closed-form solution. Therefore, a numerical approach is required. The problem is integrated with two-level explicit Euler time stepping and second-order finite differences approximation used for spatial discretization. For all computations, 100 uniformly distributed computational nodes and dimensionless time step $10^{-4}$ are used.

In the beginning of the simulation no regolith is present and therefore mechanical weathering is treated as the only active process. Mass wasting starts when the weathered mantle appears on the slope. Movement rate of the weathered material depends mainly on the slope angle. As the angle is not uniform (note that in the beginning the material is transported only within the small part in the middle of the domain) it results in a non-uniform thickness of the weathered mantle. Weathered mantle protects the bedrock from mechanical weathering and due to the non-uniform coverage, mechanical weathering becomes more intense on more exposed parts of the domain. This increasingly deforms the initial shape of the slope and the cycle stops when all processes are in the equilibrium so that the amount of mechanical weathering and corrosion is equal: the slope reaches a balanced state. From that point on- 
wards, the surface retreats uniformly, i.e. the curvature and inclination of the slope remain unchanged.

We are especially interested in the dynamics of the slope shape with respect to the ratio between corrosion and weathering $A_{1} / A_{2}$.Three examples of system dynamics are presented. For all cases $A_{3}=5 \cdot 10^{3}$, $A_{4}=2$ and $\xi=0.2$ are set. Details about the examples setup can be found in Table 1. For all three cases slopes at three different dimensionless values of time are presented $\tilde{t}=1,50,100$. As we are interested the shape of the slope the results are shifted by a average height $y_{\text {avg }}$.

The First example represents the development of slope with dominant mechanical weathering (Fig. 3). Such cases are usually present in the nature due to elemental influences which result in the intense mechanical breakdown of the rock or just due to the mechanical properties of bedrock. Examples can be found in colder or dryer climates where mechanical weathering is emphasized or chemical weathering is negligible. At the same time, karst rocks which are more prone to mechanical breakdown e.g. thin bedded limestone, tectonically crushed zones etc., are also less resistant to mechanical breakdown. With the dominance of mechanical weather- ing and resulting intense mass wasting, deformations in slope curvature are increased and inclination is reduced. The final outcomes of this example are slopes with lower angles and well-expressed curvature: convex in upper sections and concave in lower sections (Fig. 3).

Tab. 1: The setup of examples.

\begin{tabular}{|l|c|}
\hline & $A_{1} / A_{2}$ \\
\hline Case 1 & 0.25 \\
\hline Case 2 & 5.00 \\
\hline Case 3 & 1000 \\
\hline
\end{tabular}

The second example represents a balance between mechanical and chemical weathering (Fig. 4). In this case mechanical weathering and mass wasting are present on the slopes with sufficient inclination. Those processes modify slope curvature and inclination. When threshold inclination is reached and chemical weathering is equal or more intense than mechanical weathering, most of the mechanically fractured bedrock is dissolved in-situ. Mass-wasting processes then cease and balanced slope is subjected mainly to dissolutional lowering which
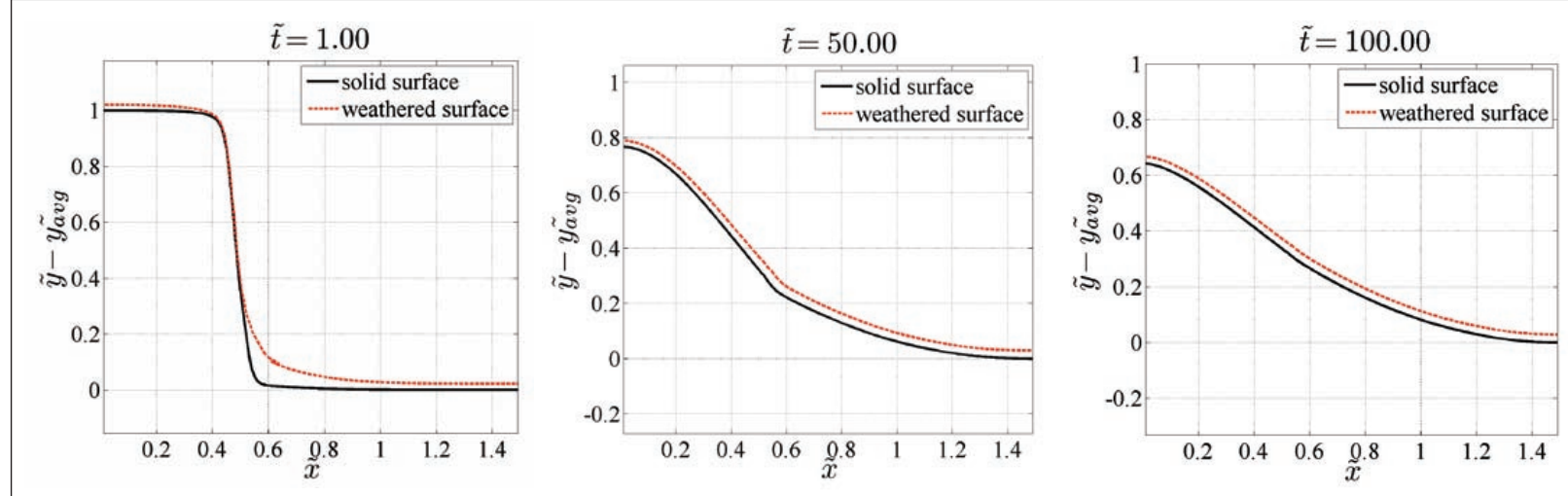

Fig. 3: Evolution of slope: Dominant mechanical weathering (example 1).
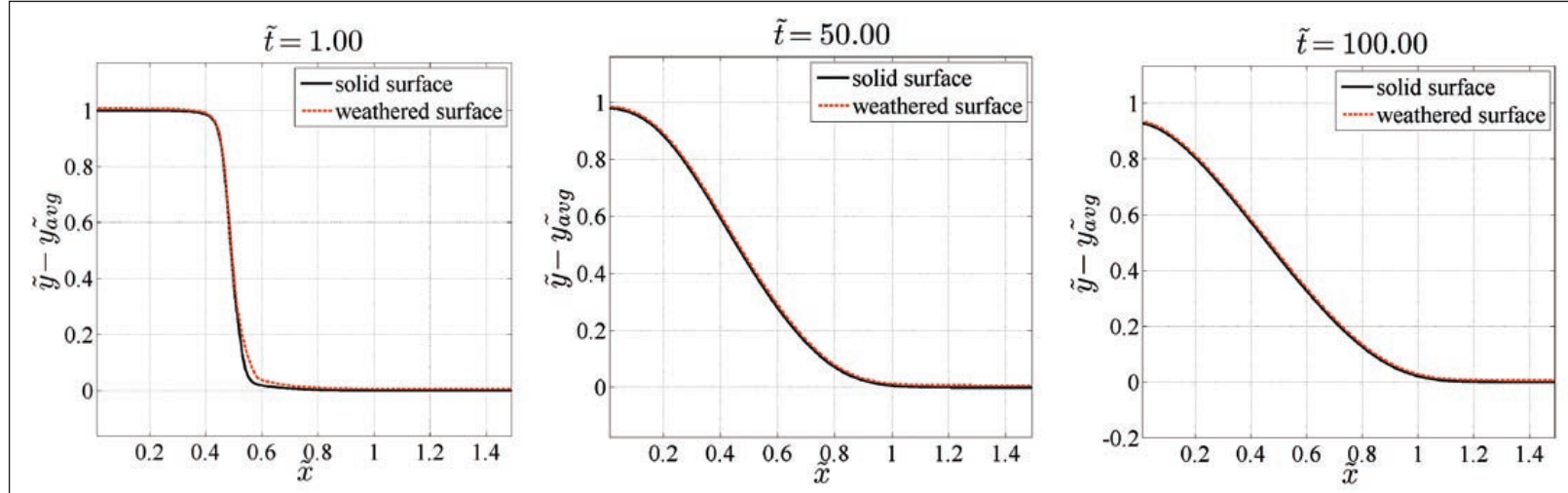

Fig. 4: Evolution of slope: Balanced mechanical and chemical weathering (example 2). 

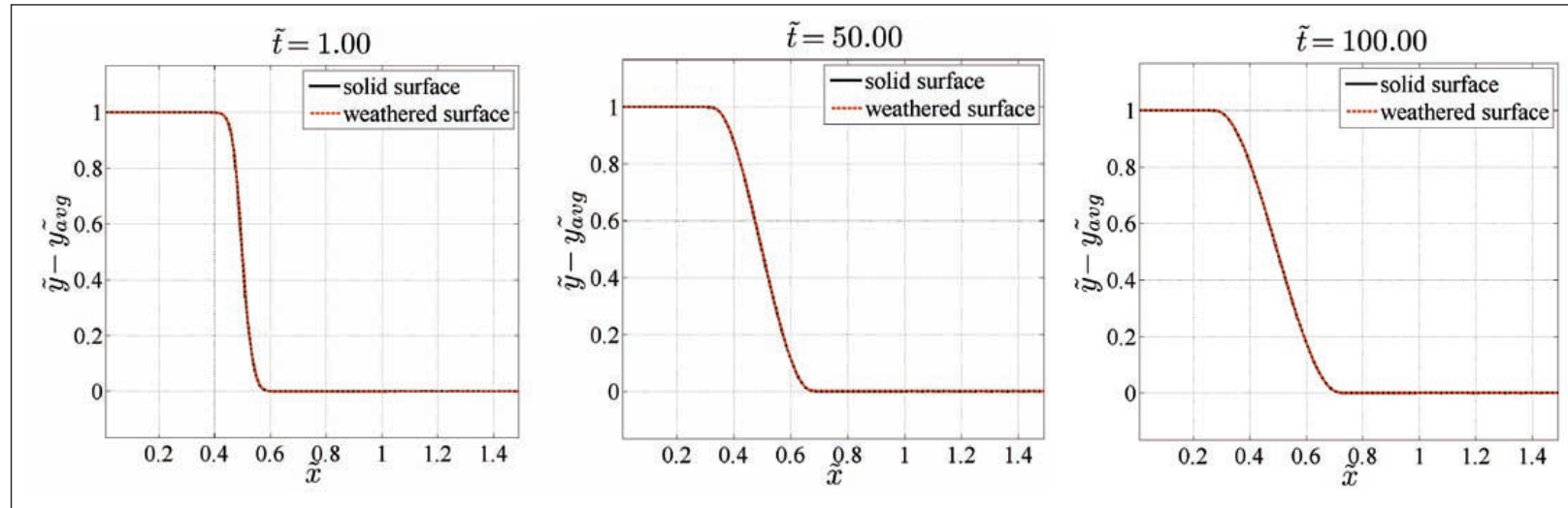

Fig. 5: Evolution of slope: Dominant chemical weathering (example 3).

does not affect curvature or inclination of the slope. In the nature, this situation is common in most of the karst environments where mechanical and chemical weathering combine. Moderately inclined slopes appear; their balanced-state inclination and curvature depend on local lithological, structural and climatic settings.

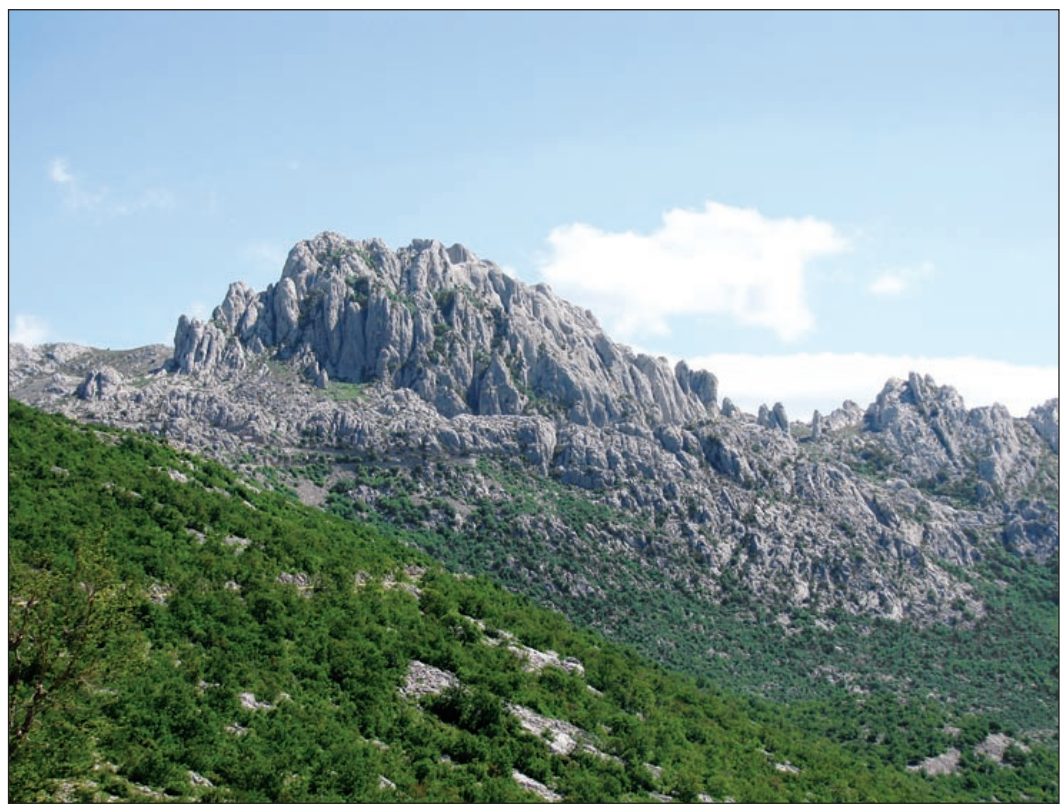

The last example represents the slope development with chemical weathering playing the dominant role (Fig. 5). Chemical weathering is dominant already in 'initial' development of the slope and it is more intense than the dynamics of mechanical breakdown of the rock. As a result most of the weathered mantle is dissolved in-situ and no mass wasting process is present. The most vivid example in the nature are carbonate rocks in hot humid climates, but it is also present in massive mechanically resistant limestones in other climates. In this case, slope curvature is not significantly changed due to mass wasting processes and the inclination is preserved.

Fig. 6: An example of massive limestone slopes where mechanical weathering is significantly lower than chemical weathering, Tulove Grede, Croatia (Photo: U. Stepišnik).

\section{CONCLUSIONS}

We have presented a simple physical model describing the formation of slopes on karst surface is presented. Despite the simplicity of the model, it shows promising agreement with the field observations (Stepišnik 2006; Stepišnik 2008).The modelling of karst slopes can be applied to various settings which appear in nature and it is simpler to predict final outcome of karst slope development which is exposed to various elements and with various bedrock properties. But the drawback of this model is absence of quantitative data from the field measurements which limits the further interpretation. 
Therefore this paper represents just the starting point for further investigations on the topic. Future work will focus on the comparison of the present model with field data as well as on the precise determination of the model constants.
From the physical model point of view, the model has to be upgraded with better treatment of weathered material transport, as well as it has to be generalized to two dimensional domain. Further improvements have to follow more detailed field observation and comparison with the model results.

\section{ACKNOWLEDGMENT}

The author would like to express their gratitude to Slovenian Research Agency for support in the framework of programme group P2-0095 (Gregor Kosec).

\section{LITERATURE}

Aderson, M. G. \& K.S. Richards, 1987: Slope stability: Geotehnical Engineering and Geomorphology.- Wiley \& Sons, pp. 342, New York.

Anhert, F., 1978: Process - response models of denudation at different spatial scales.- Catena Supplement, $10,1,31-50$.

Carslaw, H. S. \& J. C. Jaeger, 1959: Conduction of Heat in Solids.- Oxford University Press, pp. 520, Oxford.

Carson, M. A. \& M. J. Kirkby, 1972: Hillslope Form and Processes.- Cambridge University Press, pp. 239, Cambridge.

Chorley, R. J. \&B. A. Kennedy, 1971: Physical Geography, a Systems Approach.-Prentice-Hall, pp. 370, London.

Kamenomostskaya, S.L., 1961: On Stefan's problem. Matematicheskii Sbornik, 95, 489-514.

Kaufmann, G., 2002: Karst landscape evolution.- In: Gabrovšek. F (ed.) Evolution of Karst: from Prekarst to Cessation. ZRC Publishing, pp. 243-258., Ljubljana.

Kaufmann, G., 2009: Modelling karst geomorphology on different time scales.- Geomorphology, 106, 62-77.
Kirkby, M. J., 1978: Hillsope Hidrology. Wiley \& Sons, pp. 139, Chichester and New York.

Meirmanov, A. M. C., 1992: Stephan Problem.-Walter De Gruyter, pp. 250, Berlin.

Šarler, B., 1995: Stefan's work on solid-liquid phase changes.- Engineering Analysis with Boundary Elements, 16, 83-92.

Stepišnik, U., 2006: Loamy sediment fills in collapse dolines near the Ljubljanica river springs, Dinaric karst, Slovenia.- Cave \& Karst Science, 33, 3, 105110 .

Stepišnik, U., 2008: The application of electrical resistivity imaging in collapse doline floors: Divača karst, Slovenia.- Studia Geomorphologia Carpatho - Balcanica, 42, 41-56.

Summerfiled, M.A., 1996: Global geomorphology: an introduction to study of landforms.- Longmann, pp. 537, Burnt Mill. 